\title{
The Impact of Previous Online Course Experience on Students' Perceptions of Quality
}

\author{
Emily Hixon and Casimir Barczyk \\ Purdue University Calumet \\ Penny Ralston-Berg \\ Penn State World Campus \\ Janet Buckenmeyer \\ Armstrong State University
}

\begin{abstract}
The purpose of this paper is to explore whether experienced online students (who have completed seven or more online courses) perceive the quality of their courses differently than novice online students (who have completed three or fewer online courses) or students with an intermediate level of online course experience (those who have completed four to six online courses). Overall, 3,160 online students completed a survey which asked them to indicate the extent to which statements derived from the Quality Matters rubric contributed to student success. The results indicate that students rated some items differently based on their previous online course experience. Novice online learners felt that having netiquette guidelines clearly stated was more important than experienced online learners. Experienced learners rated several items as being more important than novice and/or intermediate online learners, including items related to self-introductions, appropriateness of assessments, relevance and quality of instructional materials, clarity of requirements for interaction, ease of navigation, and availability of required technologies. The implications of these findings for course designers and instructors are discussed.
\end{abstract}

\section{Introduction}

Quality online learning experiences are critical to ensuring positive and beneficial student experiences in online formats. Quality Matters ${ }^{\mathrm{TM}}(\mathrm{QM})$ is a program that provides quality assurance through a research-based rubric for online course design (Ralston-Berg, 2014). The program is designed 
to assess courses using eight standards, which when met, provide evidence of the quality and integrity of online course offerings. The rubric underlying the QM program is based on research findings of content experts and instructional designers - the knowledge specialists who have the expertise to define what constitutes quality in online courses. But scholars such as Feigenbaum (1983), Crosby (1979), Deming (1986), and Juran (1989), to name a few, contend quality is not based solely on conformity to specifications as defined by manufacturers or providers of service, but also on the perceptions of consumers. In the educational context, this means that quality is defined by the perceptions of students. In essence, quality means satisfying students' needs, exceeding their expectations, and maximizing their positive experiences in educational programs (Summers, 2006, p. 51).

In this paper we examine whether there are differences between online students-the consumers-based on students' past experiences with online learning and whether those differences affect their perceptions of the quality in their online courses. This advances the work of Ralston-Berg (2014) and Hixon, Buckenmeyer, and Barczyk (2015) on hearing the voice of the student on issues of course quality. Without a doubt, there are differences in various parts of the instructional system. There is considerable heterogeneity in the makeup of academic programs, majors, courses, and even instructors offering the same learning material. It is reasonable to suggest that there is also a fair amount of heterogeneity in the composition of university student groups, including the groups of students taking online courses. One difference that may affect the perceptions of quality in online courses is experience, i.e., the extent to which students have had a prior background in online learning. It is believed that students new to online education-novices-have a different perception of what constitutes quality in courses, as compared to those who have had a considerable background in online instructionexperienced online learners.

Organizationally, this paper is structured into four sections. The first is a review of the literature and a statement of the research questions. The second is a description of the method used to conduct the study. The third is a summary of the statistical findings related to demographics and the research questions. The fourth section is a discussion of the results, a description of the study's limitations, and a summary of implications for teaching and future research.

\section{Review of the Literature and Statement of Research Question}

Over the past ten years, the number of online courses and overall student enrollment in online courses has increased dramatically. For example, in 2013, the number of additional students taking an online course continued to grow at a rate far in excess of overall enrollments with 7.1 million students taking at least one online course (Allen \& Seaman, 2014). In other words, about one-third of all eligible course enrollments that year were online.

Among academic leaders, a growing concern revolves around overall student retention (Allen \& Seaman, 2014). Funding and other metrics indicating success are tied to an institution's student retention rate. Studies of online retention rates confirm that many colleges and universities retain fewer online students than their face-to-face counterparts (Fetzner, 2013). One way to address the issue of student retention is to ensure that online courses are at least the same quality as traditional courses.

\section{Quality Matters ${ }^{\mathrm{TM}}$ : A Tool for Assessing Online Course Quality}

Quality Matters ${ }^{\mathrm{TM}}(\mathrm{QM})$ is an international organization facilitating broad inter-institutional collaboration and a shared understanding of online course quality (MarylandOnline, 2014). QM provides a subscription-based, faculty-centered, peer review process that is designed to certify the quality of online courses. This peer review process centers around the QM Rubric which is comprised of eight general 
research-based standards and forty-three specific elements developed from empirical evidence demonstrating that they had a positive impact on student learning. Specifically, the eight standards included in the 2008-2011 QM rubric are:

- Course Overview and Introduction

- Learning Objectives

- Assessment and Measurement

- Instructional Materials

- Learner Interaction

- Course Media \& Technology

- Learner Support

- ADA Compliance

Each standard includes a number of indicators, each of which is ranked in importance and assigned a weight, where Essential = 3, Very Important = 2, and Important $=1$.

The faculty-centered QM rubric emphasizes navigability, interaction, and the instructional alignment of learning objectives to materials, activities, and assessments. The QM rubric continues to evolve based on the research literature related to online course design. Shattuck and Diehl (2011) completed a thorough review of the relevant literature and compiled a summary of the research supporting the 2011-2013 Edition of the QM rubric. The extensive research supporting the QM rubric lends credibility to the instrument. Ralston-Berg (2014) asserted that students are the consumers of courses and they may have a differing perspective on what constitutes a quality-oriented course especially in terms of what is essential, very important, and important to student success. This notion is supported by Youger and Ahern (2015) who found that courses deemed as meeting QM standards according to instructional design experts were viewed less favorably when viewed from the student perspective. The current study expands the analysis conducted by Ralston-Berg (2014) to better understand the factors that may impact students' perceptions of quality in an online course.

\section{Factors Impacting Students’ Perceptions of Online Courses}

Understanding how students (whether novices or experienced online learners) perceive successful online course experiences can provide suggestions for instructors and students to promote improved learning outcomes (Rodriguez, Ooms, \& Montanez, 2008) and ultimately increase student retention. Students' perceptions of and satisfaction in a course can be impacted by many factors including course characteristics, instructor characteristics, and student characteristics.

Course characteristics. Early work by Song, Singleton, Hill, and Koh (2004) found that the instructional design of a course was a key factor that impacts students' perceptions of an online course. A well-designed course, they noted, should clearly specify learning objectives and provide clear expectations and guidance to students to promote their success. Song and colleagues also emphasized the importance of building into a course a forum through which students can ask questions and seek clarification in order to ensure clear expectations.

Other research suggests that students taking online courses may have differing needs and that a course that accommodates varied student needs can be more favorably perceived by learners. Fike and Fike (2008) found that the degree of flexibility built into a course impacted students' satisfaction with their learning experience, and ultimately their retention in the course. Courses that incorporate group work can also be viewed more negatively by online learners who don't perceive its inclusion as sensitive to the unique schedules and demands of students enrolled in online courses (Huss \& Eastep, 2013). A separate study suggested that courses on a timeframe shorter than a traditional semester tend to be viewed 
more favorably by online learners (Ho \& Polonsky, 2012). Shorter courses can give students more options for how and when they can complete their courses.

Another critical design feature for online courses is the incorporation of student support. The extent to which students feel supported is a major factor impacting their satisfaction with their online learning experience (Kücük, Genç-Kumtepe, \& Taşc1, 2010; Patel \& Rudd, 2012). Beyond the instructor being responsive in addressing student concerns, students recognize the importance of support functions being built into the course directly. As discussed by Thorpe, "[s]tudent support was once regarded as an add-on to pre-designed courses, but it has since been recognized that it should be considered and integrated into course design” (as cited in Lee, Srinivasan, Trail, Lewis, \& Lopez, 2011, p. 158).

Instructor characteristics. Instructors play a key role in students' online learning experiences. A study by Herbert (2006) found that faculty responsiveness to student needs was the most important variable impacting student satisfaction and their perceptions about what constitutes a good online course. Related to this, faculty providing timely feedback about student progress was also a key indicator of students' satisfaction. These findings are supported by other studies which also indicate that timely responses, instructor availability, and quality feedback are critical elements of successful online courses (e.g., Huss \& Eastep, 2013; Hodges \& Cowan, 2012; Sheridan \& Kelly, 2010).

Dziuban, Moskal, Kramer, and Thompson (2013) argue that there exists an unstated psychological contract that students use to monitor and evaluate their experiences in an online course. They wrote, “[c]learly, a disconnect in students' view of the implied promise by the instructor would produce a negative impact on satisfaction" (Dziuban et al., 2013, p. 2). Some of the elements that may be included in such contracts include the instructor's willingness to facilitate learning, ability to communicate ideas, demonstration of respect and concern for students, and commitment to student learning (as cited in Dzuiban et al., 2013).

These elements are consistent with the instructor's role as explained in the Community of Inquiry (CoI) framework (Garrison, Anderson \& Archer, 2000), especially as it relates to teaching and social presence. Much research supports the notion that successful online courses demonstrate social, cognitive and teaching presence to form a CoI (e.g., Boston et al., 2009; Garrison, Anderson \& Archer, 2000; Garrison \& Arbaugh, 2007; Garrison \& Cleveland-Innes, 2005; Rubin, Frenandes, \& Avgerinou, 2013). In online courses where a strong Community of Inquiry has developed, learners feel like they are part of a learning community of real people (social presence), that they are supported by the course and instructor in pursuing relevant learning outcomes (teaching presence), and that they create meaning and knowledge through interactions within the learning community (cognitive presence). The instructor's role in creating and sustaining such a learning environment can greatly impact students' perceptions of their online course experience.

Student characteristics. Numerous studies have found that students' levels of comfort in using the Internet and technology can greatly impact their experience in, and thereby satisfaction with, their online courses (e.g., Alenezi, Karim, \& Veloo, 2010; Chu \& Chu, 2010; Kuo, Walker, Belland \& Schroder, 2013; Liang \& Wu, 2010). Related to this, Bolliger and Halupa (2012) assessed students' anxieties related to computer use, the Internet, and online learning. They found that students' anxieties were negatively correlated with their satisfaction in an online course.

Student preparedness to be an online learner was also identified as a key component impacting students' experiences in online courses (Huss \& Eastep, 2013). Perhaps more important though than students' actual preparedness for online learning is students' perceptions of their ability to be successful online learners. Palmer and Holt (2009) found that students' confidence in their ability to communicate and learn online was related to their overall satisfaction as an online learner. 


\section{Impact of Students’ Prior Online Learning Experiences}

The above discussion on the impact of students' confidence related to learning is not a new one in the field of education. Bandura (1986) defined self-efficacy as "people's judgments of their capabilities to organize and execute a course of action required to attain designated types of performances" (p. 391). When applied to learning, much research has demonstrated that student self-efficacy is a key factor in student success. In fact, a study by Schunk (1991) found that self-efficacy is the best cognitive or affective predictor of academic success.

When applied to online education, online learning self-efficacy has been found to be a strong predictor of student satisfaction in online courses (Shen, Cho, Tsai, \& Marra, 2013). Further, the study by Shen and colleagues (2013) found that the number of online courses taken previously by a student was related to their online learning self-efficacy. Specifically, they found that students with more extensive prior online learning experience demonstrated higher self-efficacy to complete an online course and collaborate with other students on academic tasks.

A study by Wang, Shannon and Ross (2013) also found that students who have taken online courses previously utilized more effective learning strategies in their online courses. Further, students who used more effective learning strategies also demonstrated increased motivation for their online coursework. These findings suggest that students with prior online learning experiences are better suited to complete their online courses successfully. Not only are students with prior experience more likely to be successful learners, they also experience benefits in the affective domain of learning such as better attitude and satisfaction with their courses (Astani, Ready, \& Duplaga, 2010; Ivers \& Carter-Wells, 2005; Rodriguez et al., 2008; Wang, Shannon, \& Ross, 2013).

These findings suggest that students who have more extensive prior online learning experience are better prepared to be successful, have more confidence in their ability to be successful, and thus tend to have more favorable views of online learning. This is in contrast to a

study by Artino (2011) which found that students with online experience consistently perceived quality lower on the items for the Quality Matters standards. What is consistent in these findings, however, is that prior online learning experience seems to impact students' perceptions of online courses.

\section{Statement of Research Question}

While there is a stronger focus on online learning nationwide, there is still much that is not known about today's online learner. As discussed above, the impact of learners' previous online learning experiences has been explored in some areas, but this study seeks to expand that research by examining its impact on students' perceptions of course quality. More specifically, this study seeks to answer whether students' perceptions of online course quality differ based on the extent of their previous online learning experience.

\section{Respondents}

\section{Method}

The respondents in this study consisted of 3,160 students who had previously taken or were currently enrolled in online for-credit courses at 31 colleges or universities across 22 states. The majority of respondents were female $(n=1813)$, 834 were male, and 512 declined to provide their gender. Respondents ranged in age from 18 to over 65 with the largest group consisting of individuals between the ages of 26 and 44 (see Table 1 ). 
Table 1 Age of Respondents

\begin{tabular}{|l|l|l|}
\hline Age & $\boldsymbol{n}$ & $\mathbf{\%}$ \\
\hline $18-25$ & 750 & $23.7 \%$ \\
\hline $26-44$ & 1341 & $42.5 \%$ \\
\hline $45+$ & 562 & $17.8 \%$ \\
\hline Not specified & 506 & $16 \%$ \\
\hline
\end{tabular}

The majority of respondents were employed full-time and attending school part-time, as indicated in Tables 2 and 3.

Table 2 Respondents’ Employment Status

\begin{tabular}{|l|l|l|}
\hline Employment status & $\boldsymbol{n}$ & $\mathbf{\%}$ \\
\hline Not employed & 580 & $18.4 \%$ \\
\hline Employed part-time & 513 & $16.2 \%$ \\
\hline Employed full-time & 1537 & $48.7 \%$ \\
\hline Not specified & 529 & $16.7 \%$ \\
\hline
\end{tabular}

Table 3 Respondents' Student Status

\begin{tabular}{|l|l|l|}
\hline Student status & $\boldsymbol{n}$ & $\mathbf{\%}$ \\
\hline Part-time & 1449 & $45.9 \%$ \\
\hline Full-time & 1171 & $37.1 \%$ \\
\hline Not specified & 539 & $17.1 \%$ \\
\hline
\end{tabular}

The respondents indicated their current level of education as listed in Table 4.

Table 4 Respondents' current education level

\begin{tabular}{|l|l|l|}
\hline Current education level & $\mathbf{N}$ & $\mathbf{\%}$ \\
\hline First year (Freshman) & 258 & $8.2 \%$ \\
\hline Second year (Sophomore) & 348 & $11.0 \%$ \\
\hline Third year (Junior) & 405 & $12.8 \%$ \\
\hline Fourth year (Senior) & 509 & $16.1 \%$ \\
\hline Graduate & 711 & $22.5 \%$ \\
\hline Does not apply & 300 & $9.5 \%$ \\
\hline Not specified & 628 & $19.9 \%$ \\
\hline
\end{tabular}

The respondents were from 25 different academic disciplines and had varying amounts of online course experience ranging between 1 and 9 or more completed courses. Table 5 shows the number of online courses completed by respondents. 
Table 5 Number of Online Courses Completed by Respondents

\begin{tabular}{|l|l|l|}
\hline $\begin{array}{l}\# \text { of Online Courses } \\
\text { Completed }\end{array}$ & $\boldsymbol{n}$ & $\mathbf{\%}$ \\
\hline 0 & 292 & $9.2 \%$ \\
\hline $1-2$ & 665 & $21.1 \%$ \\
\hline $3-4$ & 466 & $14.8 \%$ \\
\hline $5-6$ & 332 & $10.5 \%$ \\
\hline $7-8$ & 199 & $6.3 \%$ \\
\hline $9+$ & 657 & $20.8 \%$ \\
\hline Not specified & 548 & $17.3 \%$ \\
\hline
\end{tabular}

The vast majority of respondents completed online courses that were cohort-based and followed a fixed schedule for all students. Only 6.9\% $(n=219)$ of respondents indicated that the online courses they had previously completed were exclusively self-paced-that is, students completed the course on their own schedule (687 respondents declined to indicate the format of their previous courses).

\section{Survey Instrument}

The survey instrument consisted of 43 items derived from the rubric associated with the 20082010 QM Standards ${ }^{1}$. As previously mentioned, the QM rubric is faculty-centered. Although based on extensive research, the question remained-Would students agree that the standards in the QM rubric were important? The specific standards included in the rubric were originally written in faculty-centered language. In order for online students to rank these rubric items, each standard was first converted to student-centered language. For example, the specific standard, "The self-introduction by the instructor is appropriate” (MarylandOnline, 2006), was modified to read, "The instructor introduces her- or himself.” Each course characteristic was then rated by students on a four-point Likert type scale where 0 corresponded to being not at all important-does not contribute to my success; 1 corresponded to important; 2 corresponded to very important; and 3 corresponded to essential—could not succeed without it. When providing their rating to each course characteristic question, respondents were instructed to consider only the online course environment. The survey instrument also contained several demographic items and three open-ended questions on course quality. The survey collected demographic information on the number of online courses completed previously, the format of those courses, the amount of time spent working on online coursework, as well as technology comfort level, disability status, age, gender, race, employment status, military experience, family status, educational level, and current major of study. The open-ended items asked respondents to comment on other valuable features in their online courses, the biggest obstacles to online learning, and what makes a quality online course.

\section{Procedure}

The survey instrument was administered electronically through a unique URL furnished by a designated contact person at each cooperating institution. The respondents received the URL by means of an e-mail message or a link posted to the home page of the institution's course management system. They

\footnotetext{
${ }^{1}$ The items included on the survey were based off the 2008-2010 Quality Matters rubric. The complete list of adapted rubric items can be found in an article by Ralston-Berg (2014). Replication of this study would necessitate revision of the survey items to align with the current (2014) Quality Matters standards and indicators.
} 
also received URLs by means of an announcement in an online course in which they were enrolled. Data were collected from all cooperating institutions and aggregated into a cumulative data file.

\section{Results}

To examine the impact of previous online course experience on students' perceptions of quality in online courses, previous online experience was operationalized into three categories as listed in Table 6.

Table 6Number Of Respondents By Level Of Previous Online Course Experience

\begin{tabular}{|l|l|}
\hline & $n$ \\
\hline Novice (taken less than 3 online courses) & 955 \\
\hline Intermediate (taken 3-6 online courses) & 797 \\
\hline Experienced (taken 7 or more online courses) & 855 \\
\hline
\end{tabular}

ANOVA tests were conducted to compare the means for each QM-related statement across the three groups (novice, intermediate, and experienced online learners). For the majority of survey items (33 of 43 items), participants rated the items similarly regardless of their level of previous experience with online courses. The survey items that varied significantly across the three groups are listed in Table 7.

Table 7 Survey Items That Vary Based On Previous Online Course Experience

\begin{tabular}{|l|l|l|l|l|}
\hline $\begin{array}{l}\text { QM } \\
\#\end{array}$ & QM-based questionnaire statement & df & F & $\mathbf{p}$ \\
\hline 1.3 & $\begin{array}{l}\text { Etiquette (or “netiquette”) guidelines for how to behave online are } \\
\text { clearly stated }\end{array}$ & 2,2601 & 3.63 & .03 \\
\hline 1.5 & I am asked to introduce myself to the class. & 2,2602 & 4.50 & .01 \\
\hline 3.4 & $\begin{array}{l}\text { Assessments (quizzes, exams, papers, projects, etc.) are } \\
\text { appropriately timed within the length of the course, varied, and } \\
\text { appropriate to the content being assessed. }\end{array}$ & 2592 & 3.81 & .02 \\
\hline 4.1 & $\begin{array}{l}\text { Instructional materials contribute to the achievement of the course } \\
\text { and module/unit learning objectives. }\end{array}$ & 2,2600 & 5.33 & .01 \\
\hline 4.3 & $\begin{array}{l}\text { Instructional materials have sufficient breadth, depth, and currency } \\
\text { for me to learn the subject. }\end{array}$ & 2,2588 & 3.55 & .03 \\
\hline 5.4 & $\begin{array}{l}\text { Requirements for my interaction with the instructor, content, and } \\
\text { other students are clearly explained. }\end{array}$ & 2,2603 & 6.63 & $<.01$ \\
\hline 6.3 & $\begin{array}{l}\text { Navigation throughout the online components of the course is } \\
\text { logical, consistent, and efficient. }\end{array}$ & 2,2590 & 5.54 &.$<01$ \\
\hline 6.4 & $\begin{array}{l}\text { Technologies required for the course are readily available - } \\
\text { provided or easily downloadable. }\end{array}$ & 2,2585 & 3.33 & .04 \\
\hline 6.5 & $\begin{array}{l}\text { The course components are web-based or easily downloaded for use } \\
\text { offline. }\end{array}$ & 2,2588 & 3.27 & .04 \\
\hline 8.4 & Course ensures screen readability. & 2,2592 & 4.27 & .01 \\
\hline
\end{tabular}


Post-hoc analyses using Tukey HSD were conducted to examine differences between the three levels of online course experience for each of the items found to differ significantly. For the item addressing the importance of etiquette/netiquette guidelines being clearly stated (QM 1.3), novice online learners $(M=1.51, S D=.93)$ rated this item as significantly more important than experienced online learners $(M=1.39, S D=.91, p=.02)$.

Another item related to the course overview and introduction (QM Standard 1) where there was significant variance among the responses of those with differing levels of online learning experience relates to perceptions of the importance of having the opportunity to introduce oneself to the class (QM 1.5). Specifically, novice online learners $(M=.98, S D=.96)$ felt it was significantly less important that they be asked to introduce themselves to the class than did experienced online learners $(M=1.11, S D=$ $.96, p<.01)$.

Experienced online learners also rated three items related to the alignment of instructional components of the course to be more important than those with less online learning experience. Experienced online learners $(M=2.54, S D=.63)$ indicated a greater importance than novice online learners $(M=2.46, \mathrm{SD}=.66, p=.02)$ for assessments to be appropriately timed, varied, and appropriate to the content being assessed (QM 3.4). Similarly, experienced online learners $(M=2.36, S D=.69)$ felt it was more important than novices $(M=2.25, S D=.74, p<.01)$ for instructional materials to contribute to the achievement of the course and unit learning objectives (QM 4.1). Also related to the alignment of instruction, experienced online learners rated as more important than intermediate online learners an item related to the appropriateness of the instructional materials (QM 4.3). Specifically, experienced online learners $(M=2.38, S D=.68)$ rated the item, "Instructional materials have sufficient breadth, depth, and currency for me to learn the subject" as more important than online learners with an intermediate level of experience $(M=2.29, S D=.74, p=.04)$.

Learners with more extensive online experience (those who have taken seven or more online courses) differed in their ratings of items related to clear expectations for interaction and ease of navigation. In general, those with more online experience rated these items as more important than online learners with less experience. Experienced learners $(M=2.43, S D=.69)$ placed greater value on the requirements for interaction with the instructor, content, and other students being clearly stated (QM 5.4) than did novice $(M=2.32, S D=.80, p<.01)$ or intermediate learners $(M=2.32, S D=.76, p<.01)$. Similarly, experienced learners $(M=2.57, S D=.62)$ indicated greater importance for the course navigation to be logical, consistent, and efficient (QM 6.3) than did novice ( $M=2.47, S D=.70, p=.01$ ) or intermediate learners $(M=2.48, S D=.70, p=.02)$.

Experienced online learners also differed from intermediate online learners on several items related to course technology. Experienced learners $(M=2.66, S D=.59)$ felt it was more important than intermediate online learners $(M=2.59, S D=.66, p=.04)$ for the required technologies to be readily available (QM 6.4). Similarly, experienced learners $(M=2.52, S D=.70)$ more highly valued course components being web-based or easily downloaded for use offline (QM 6.5) than did novice online learners $(M=2.44, S D=.75, p=.04)$. Lastly, experienced leaners $(M=2.37, S D=.70)$ rated more highly than intermediate online learners $(M=2.25, S D=.85, p=.01)$ the item stating that the course ensures screen readability (QM 8.4).

\section{Discussion}

The literature on quality management stresses the importance of hearing the voice of the customer so that needs for products and services are met and expectations are exceeded (Juran, 1989). Defining the customer, however, is often problematic. The same is true in the context of the educational environment, 
particularly as it relates to online learners. While it may be inappropriate to regard students strictly as customers, it is appropriate to say that they share certain commonalities, one of which relates to their group heterogeneity. Students in the same course are not homogeneous as some faculty believe. There is great variance in the needs and expectations of students taking online courses. There is also variance in their online course experience. Some have limited or no experience in online learning, while others have a significant background in online education.

In this study, novice online learners were defined as those who had taken less than three online courses previously, intermediate online learners were students who had taken between three and six online courses in the past, and experienced online learners were students who had taken more than seven online courses. These groups were defined to reflect the level of experience that a student could reasonably be expected to gain based on the number of their prior online learning experiences. It is likely that students who had taken less than three online courses would be at the start of an online program or had dabbled in online courses in a traditional program. These novice online learners may be inexperienced in using a learning management system and other course technologies, and may be unfamiliar with typical instructional approaches and conventions used in online courses. They may not be aware of what they don't know and may still be getting acclimated to the learning system. Intermediate online learners have likely become more proficient in using a learning management system and other technologies, and they may have at least been exposed to commonly used instructional approaches. These intermediate students, however, may not yet have the confidence or proficiencies of more experienced online learners. Finally, experienced online learners, who have taken at least seven online courses previously, have completed many credit hours in the online environment. Students with this level of experience can reasonably be expected to have more comfort with course technology, structure, and participation.

The results of this study stand for the proposition that prior online course experience colors students' perceptions of the quality of their online course. While some differences in importance ratings between respondents with varied levels of prior online learning experience are mathematically small, the large sample size gives power to these differences. Though there are many areas where students' perceptions of quality do not vary based on prior online learning experience, the findings of this study highlight several elements of online courses where students with a great deal of background in online education-experienced online learners as defined in this study-perceive the quality of their courses differently than those who have a more limited background in online education.

This finding that online students differ in their perceptions of quality based on prior online experience is generally consistent with Ralston-Berg (2014) who contends that students' perceptions of online course quality vary from those who designed the QM standards. The results of this study run counter to the work of Artino (2011) who found that students with online course experience perceived quality lower on items related to the QM standards.

The findings of this study suggest that prior online learning experience can impact the value students place on the cohesiveness of the online course experience. More experienced online learners seem to recognize the importance of online courses having clear expectations, alignment of instructional components, logical navigation, and ready availability of required tools and resources, as discussed below.

Experienced online learners, as contrasted with their novice counterparts, indicated a greater need to have expectations for interaction clearly defined. This concern is connected to QM statement 5.4. Research has shown that interaction is a key factor impacting students' satisfaction in online courses (e.g., Ali and Ahmad, 2011, Lee, 2012). Experienced online learners seem to appreciate the importance of having clear expectations for their performance, especially as it relates to interaction with course content, 
instructors, or their peers. Experienced learners may seek this clarity because they have encountered differing expectations for interaction in the online courses that they have completed. As such, these learners seem to recognize that it is important to establish early expectations of what is necessary and required of them in terms of course-related interactions.

Experienced online learners also appear to value the alignment of instructional components more than their counterparts with less previous online learning experience. This relates to QM statements 4.1, 4.3, and 5.4. Appreciating the value of instructional alignment constitutes the core of successful course design, and there is much research supporting the absolute fundamentality of strong instructional alignment in online courses (e.g., Bento \& White, 2010; Gaytan \& McEwen, 2007; Rogerson-Revell, 2015). In a nutshell, when developing instruction, it is critical that the learning objectives, learning materials/activities, and assessments complement one another. If there is misalignment between these components, the learning experience is compromised. This is true for all types of instruction and even more critical in the online environment where students do not have the benefit of a face-to-face instructor who regularly reinforces the connection between the objectives, the assigned reading material, the activities, and the assessment mechanisms. Given that students strive toward course success, it appears that experienced online learners have a better understanding of the importance of course alignment. They have come to know how the connections between learning objectives, materials, and course assessment fit together to promote student success.

Another issue that is central to students' perceptions of quality in online offerings is knowing where to find the necessary materials and information to perform well in their courses. Our findings indicate that all levels of online learners place significant value on the ease of navigability within a course. However, experienced online students have a greater need and appreciation for course navigation that is logical, consistent, and efficient than their less experienced counterparts. This relates to QM statement 6.3. The reason underlying this finding may be that learners who have taken many online courses have likely experienced some courses that were more easily navigated than others. Due to the sheer volume of online courses they have completed, experienced online learners may have encountered challenges in their learning due to issues in website navigability. It is conceivable that these challenges resulted in experienced online learners having a greater need for well-designed and easily navigable courses.

A finding related to QM statements 6.4 and 6.5 is that students with extensive online course experience, as contrasted with novice or intermediate level online learners, value having required technologies and course components easily available. Learners with more experience understand this quality issue. They realize that having a navigable website entails being able to easily access required elements of their courses and the necessary technological tools, without which they are unable to perform well and earn their desired grades. Novice online learners apparently are not sufficiently sophisticated to realize that they need these tools and course components to perform well. It is thought that this knowledge comes with learning maturity and experience in online education.

Another critical issue that drives students' success in online courses is having the opportunity to introduce themselves to the class. This issue is related to QM standard 1.5. Experienced online learners valued this significantly more than novice learners. Perhaps the students who place a higher value on introductions appreciate the importance of establishing stronger learning communities because it impacts their learning and sense of connectedness. This would be consistent with the CoI framework, specifically as social and cognitive presence overlap (e.g., Garrison, Cleveland-Innes, \& Fung, 2010). The research on social networking also appears to provide some support for this proposition (e.g., Barczyk \& Duncan, 2013). It may be even more relevant for older students who are re-engaging in the education process to appreciate the importance of introductions as they return to learning in the online environment. These students may see greater salience of their life experiences to the content of their courses and feel that they have much to contribute - thereby creating a richer community of practice. Through these course 
introductions fellow students may feel a greater connection and recognize the power in learning from their classmates.

Finally, it was found that experienced online students recognize the importance of screen readability, a finding related to QM statement 8.4. Being able to access and read information presented in a course is central to students' need to clearly understand what they need to perform well in an online course. Good course navigability enables students to have access to critical information that facilitates learning and promotes course success.

There is one area where the expectations of novice online learners are greater than those of experienced learners. Novice online learners feel that it is more important for a course to clearly address issues of etiquette/netiquette than their more experienced counterparts. The reason may be that novice learners have limited online learning experience and as such, they may think that they do not know what types of behaviors are appropriate in an online course setting. This may represent an expectation that novice learners need to have clarified. Further, novice online learners may need more guidance on how to appropriately engage in their distance learning courses. It seems reasonable to speculate that experienced online learners are less concerned with etiquette because they have become familiar with these and related issues through their prior online learning experiences.

\section{Conclusions}

This study found that there are differences in the perceptions of online course quality based on a student's level of previous online course experience. Perceptions of course quality were influenced by the extent to which students were experienced, intermediate, or novice online learners. For the most part, experienced online learners had the greatest needs and expectations of their instructors for course quality. They understood that performing optimally required that their courses had to be designed well and presented in a logical, consistent, and efficient manner. Novice online learners indicated that it was important for their courses and instructors to address clearly and early in the course matters related to proper netiquette.

The results of this study reinforce the importance of many key design features for online courses as articulated by Quality Matters. Recognizing the high expectations for online courses especially from experienced online learners, faculty and course designers need to ensure that their online courses do the following:

- Demonstrate strong alignment of course objectives, assessments and learning activities. Instructors need to also help learners see the connection between various course elements so they can better understand their path to success in the course.

- Exhibit clear organization, easy navigation and optimal readability by students. Making sure that students can easily access required technologies and materials is also recognized by experienced learners to be a key to their success.

- Clearly state expectations for student performance, especially as it relates to interaction with the course content, instructor, and their peers.

- Create opportunities for students to introduce themselves to the class and reinforce to students the importance of this activity in creating a supportive and effective learning community.

- List and explain netiquette guidelines. Even though it may seem that learners are more comfortable in the online environment with each passing year, the results of this study suggest that students in online courses, especially those with limited online course experience, still need and seek out guidance on acceptable behaviors in online courses. 


\section{Limitations and Future Research}

The findings of this study are based on students' responses to survey items asking about their perceptions of quality in online courses. The survey method is an efficient way to collect data and it allowed the researchers to gather data from over three thousand online students. However, surveys also have limitations that cannot be ignored. Collecting data via a single data source that relies on participants' self-responses increases the risk of mono-method bias and social-desirability bias. Since participants didn't know the researcher's focus and there were not clear socially desirable responses, the impact of the self-responses should be minimal. Collecting additional data from other sources and/or via other methods would help to triangulate, support, and further explain the findings presented in the current study.

Additionally, future research should seek to explore other student characteristics that may impact students' perceptions of quality in online courses. Many studies look at the experiences and perceptions of online learners as a whole. But this study reinforces that online learners are not all the same and that various characteristics of online learners may impact their experiences and perceptions. Other learner characteristics to explore in relation to perceptions of online course quality may be age, gender, type of educational institution, employment status, family situation, and disabilities.

\section{References}

Alenezi, A. R., Karim, A. M., \& Veloo, A. (2010). An empirical investigation into the role of enjoyment, computer anxiety, computer self-efficacy and Internet experience in influencing the students' intention to use e-learning: a case study from Saudi Arabian government universities. The Turkish Online Journal of Educational Technology, 9(4), 22-34.

Ali \& Ahmad (2011). Key factors for determining students' satisfaction in distance learning courses: a study of Allama Iqbal Open University. Contemporary Educational Technology, 2(2), 118-134.

Allen, I. E., \& Seaman, J. (2014). Grade change: tracking online education in the United States. Babson Park, MA: Babson Survey Research Group and Quahog Research Group. Retrieved from http://www.onlinelearningsurvey.com/reports/gradechange.pdf

Artino, K. (2011). Undergraduate students perceptions of a quality online course: online experience versus no online experience (Unpublished doctoral dissertation). University of Akron, Akron, $\mathrm{OH}$.

Astani, M., Ready, K. J., \& Duplaga, E. A. (2010). Online course experience matters: investigating students’ perceptions of online learning. Issues in Information Systems, 10(2), 14-21.

Barczyk, C. C. \& Duncan, D. G. (2013). Facebook in higher education courses: an analysis of students' attitudes, community of practice, and classroom community. International Business and Management, 6(1), 1-11.

Bandura, A. (1986). Social foundations of thought and action. Englewood Cliffs, NJ: Prentice-Hall.

Bento, R. F., \& White, L. F. (2010). Quality measures that matter. Issues in Informing Science and Information Technology, 7, 61-72. Retrieved from http://iisit.org/Vol7/IISITv7p061072Bento839.pdf 
Bolliger, D., \& Halupa, C. (2012). Student perceptions of satisfaction and anxiety in an online doctoral program. Distance Education, 33, 81-98.

Boston, W., Diaz, S. R., Gibson, A. M., Ice, P., Richardson, J., \& Swan, K. (2009). An exploration of the relationship between indicators of the Community of Inquiry framework and retention in online programs. Journal of Asynchronous Learning Networks, 13(3), 67-83.

Chu, R. J., \& Chu, A. Z. (2010). Multi-level analysis of peer support, Internet self-efficacy and e-learning outcomes: the contextual effects of collectivism and group potency. Computer and Education, 55, 145-154.

Crosby, P. B. (1979). Quality is free. New York: Penguin Books.

Deming, W. E. (1986). Out of the crisis. Cambridge, MA: MIT Press.

Dzuiban, C., Moskal, P., Kramer, L, \& Thompson, J. (2013). Student satisfaction with online learning in the presence of ambivalence: Looking for the will-o'-the-wisp. Internet and Higher Education, $17,1-8$.

Feigenbaum, A. V. (1983). Total quality control. New York: McGraw-Hill.

Fetzner, M. (2013). What do unsuccessful online students want us to know? Journal of Asynchronous Learning Networks, 17(1), 13-27.

Fike, D. S., \& Fike, R. (2008). Predictors of first-year student retention in the community college. Community College Review, 36(2), 68-89. doi:1569189141

Garrison, D. R., Anderson, T., \& Archer, W. (2000). Critical inquiry in a text-based environment: computer conferencing in higher education. Internet and Higher Education, 2(2-3), 87-105.

Garrison, D. R., \& Cleveland-Innes, M. (2005). Facilitating cognitive presence in online learning: interaction is not enough. American Journal of Distance Education, 19(3), 133-148.

Garrison, D. R., Cleveland-Innes, M., \& Fung, T. S. (2010). Exploring causal relationships among teaching, cognitive and social presence: student perceptions of the community of inquiry framework. Internet and Higher Education, 13(1-2), 31-36.

Gaytan, J. \& McEwen, B. C. (2007). Effective online instructional and assessment strategies. The American Journal of Distance Education, 21(3), 117-132.

Herbert, M. (2006). Staying the course: A study in online student satisfaction and retention. Online Journal of Distance Learning Administration, 9(4). Retrieved from http://www.westga.edu/ distance/ojdla/winter94/herbert94.pdf

Hixon, E., Barczyk, E., \& Buckenmeyer, J. (2015). Closing the feedback loop: hearing the student voice in course quality. Quality Approaches in Higher Education, 6(1), 26-36.

Ho, W. L., \& Polonsky, M. (2012). Marketing students' perception of traditional and intensive delivery: an exploratory study. In M. Thyne, K.R. Deans, \& J. Gnoth (Eds.), ANZMAC 2007: 3Rs, reputation, responsibility relevance. Paper presented at the Australian and New Zealand 
Marketing Academy (ANZMAC) Conference 2007 (pp. 3268-3273). Dunedin, New Zealand: University of Otago.

Hodges, C. B., \& Cowan, S. F. (2012). Preservice teachers' views of instructor presence in online courses. Journal of Digital Learning in Teacher Education, 28, 139-145.

Huss, J. A., \& Eastep, S. (2013). The perceptions of students toward online learning at a Midwestern university: what are students telling us and what are we doing about it? Inquiry in Education, 4(2). Retrieved from http://digitalcommons.nl.edu/ie/vol4/iss2/5

Ivers, I., \& Carter-Wells, J. (2005). Students' attitudes and perceptions of online instruction. Paper presented at the National Educational Computing Conference. Retrieved on November 8, 2014 from http:www.researchgate.netpublication/237338175_National_Educational_Computing_Conferen ce_2005_Philadelphia_Pennsylvania_Students'_Attitudes_and_Perceptions_of_Online_Instructio n.

Juran, J. M. (1989). Juran on leadership for quality: an executive handbook. New York: Free Press.

Kücük, M., Genç-Kumtepe, E., \& Taşc1, D. (2010). Support services and learning styles influencing interaction in asynchronous online discussions. Educational Media International, 47(1), 39-56.

Kuo, Y. C., Walker, A., Belland, B. R., \& Schroder, K. E. E. (2013). A predictive study of student satisfaction in online education programs. The International Review of Research in Open and Distance Learning, 14(1), 16-39.

Lee, J. (2012). Patterns of interaction and participation in a large online course: strategies for fostering sustainable discussion. Educational Technology \& Society, 15(1), 260-272.

Lee, S. J., Srinivasan, S., Trail, T., Lewis, D., \& Lopez, S. (2011). Examining the relationship among student perception of support, course satisfaction, and learning outcomes in online learning. Internet and Higher Education, 14, 158-163.

Liang, J. C., \& Wu, S. H. (2010). Nurses’ motivations for web-based learning and the role of Internet selfefficacy. Innovations in Education and Teaching International, 47(1), 25-37.

MarylandOnline. (2006). Research literature and standards sets support for Quality Matters review standards as of 12/5/05. Retrieved from: https://my.msjc.edu/web/ol/otc\%20otl/Additional\% 20Materials/Matrix\%20of\%20Research\%20St andards\%20FY0506.pdf

MarylandOnline. (2014). Quality Matters program. Retrieved from http://www.qualitymatters.org.

Palmer, S. R., \& Holt, D. M. (2009). Examining student satisfaction with wholly online learning. Journal of Computer Assisted Learning, 25, 101-113.

Patel, R., \& Rudd, T. (2012). Can scholarships alone help students succeed? Lessons from two New York City community colleges. New York: MDRC. Retrieved from: http://www.mdrc.org/sites/default/files/Can\%20Scholarships\%20Alone\%20Help\%20Students\%2 0Succeed\%20Full\%20Report_1_0.pdf 
Ralston-Berg, P. (2014). Surveying student perspectives of quality: value of QM rubric items. Internet Learning, 3(1), 117-126.

Rodriguez, M., Ooms, A., \& Montanez, M. (2008). Students' perceptions of online-learning quality given comfort, motivation, satisfaction, and experience. Journal of Interactive Online Learning, 7(2), 105-118.

Rogerson-Revell, P. (2015). Constructively aligning technologies with learning and assessment in a distance education master’s programme. Distance Education, 36(1),129-147.

Rubin, B., Fernandes, R., Avgerinou, M. D. (2013). The effects of technology on the Community of Inquiry and satisfaction with online courses. Internet and Higher Education, 17, 48-57.

Schunk, D. H. (1991). Self-efficacy and academic motivation. Educational Psychologist, 26, 207-231.

Shattuck, K., \& Diehl, W. C. (2011). QM literature for 2011-2013 rubric. Annapolis, MD: Quality Matters. Retrieved from https://www.qualitymatters.org/lit-review-2011-2013rubricpdf/download/QM\%20Lit\%20Review\%20for\%202011-2013\%20Rubric.pdf.

Shen, D., Cho, M. H., Tsai, C. L., \& Marra, R. (2013). Unpacking online learning experiences: online learning self-efficacy and learning satisfaction. Internet and Higher Education, 19, 10-17.

Sheridan, K., \& Kelly, M. A. (2010). The indicators of instructor presence that are important to students in online classes. Journal of Online Learning and Teaching, 6(4). Retrieved from http://jolt.merlot.org/vol6no4/sheridan_1210.htm

Song, L., Singleton, E. S., Hill, J. R., \& Koh, M. H. (2004). Improving online learning: student perceptions of useful and challenging characteristics. Internet and Higher Education, 7, 59-70.

Summers, D. C. (2006). Quality (4 ${ }^{\text {th }}$ ed.). Upper Saddle River, NJ: Pearson Education, Inc.

Wang, C., Shannon, D. M., \& Ross, M. E. (2013). Students' characteristics, self-regulated learning, technology self-efficacy, and course outcomes in online learning. Distance Education, 34(3), 302-323.

Youger, R. E., \& Ahern, T. C. (2015). Is a quality course a worthy course? Designing for value and worth in online courses. Online Journal of Distance Learning Administration, 8(1). Retrieved from http://www.westga.edu/ distance/ojdla/spring181/youger_ahern181.html 